\title{
PERCEPTIONS OF PRIVATE SECURITY \\ A CASE STUDY OF STUDENTS FROM SERBIA AND NORTH MACEDONIA
}

\author{
${ }^{1}$ Bojan Janković ${ }^{1}$, ${ }^{2}$ Vladimir M. Cvetković, ${ }^{3}$ Aleksandar Ivanov \\ ${ }^{1}$ University of Criminal Investigation and Police Studies, Belgrade \\ ${ }^{2}$ University of Belgrade, Faculty of Security Studies \\ ${ }^{3}$ University "St. Kliment Ohridski" - Skopje, Faculty of Security Studies
}

\begin{abstract}
In the last two decades of the $21^{\text {st }}$ century, the significant development of the private security industry has taken place in Serbia and North Macedonia. However, the private security industry in these two countries did not reach professional standards as in other states of the former Yugoslavia. The aim of this paper was to determine students' perception of private security and its employees. The survey data were collected using an anonymous survey of 354 students (296 from Serbia and 58 from North Macedonia). In both countries the attitudes are heterogeneous, but a relatively small number of respondents have expressed a high level of perception of private security. The research has shown that gender, as one of demographic characteristics, has its role in shaping young pexople's views on the private security, that is, the female population has more positive views about private security officers, their integrity, and the nature of the private security job. The findings offer policy-makers and private security companies the opportunity to deploy new strategies to upgrade public attitudes towards private security, especially aimed at the male population.
\end{abstract}

Keywords: private security, perceptions, students, Serbia, North Macedonia.

\section{INTRODUCTION}

In recent years, the topic of private se- for many reasons. The first reason is the curity has attracted increasing attention increase in the volume of jobs entrusted from the professional and scientific public to the private security industry, as well as

1 Corresponding author: bojan.jankovic@kpu.edu.rs 
the increase in the number of employees (Steden \& Sarre, 2007a, 2007b). Today, in many countries, the number of employees in the private security sector is equal to or significantly greater than the number of police officers (Nalla, Gurinskaya, \& Rafailova, 2017; Nalla, Maxwell, \& Mamayek, 2017; Paek, Nalla, \& Lee, 2018) security officers: police officers - the USA 3:1; Hong Kong 5:1 (Nalla et al., 2017). Another reason for the public's attention is that the security industry is struggling with the uncertainty of its status and reputation, which has been tarnished by the high turnover of low-skilled, low-paid staff, shown in the public to be prone to commit crimes and violence (Hansen Löfstrand, Loftus, \& Loader, 2016).

In post-socialist countries, the transformation of socialism into a capitalist system resulted in return of nationalized property and a significant increase in private property, that is, "the rebirth of private property" that influenced the development and organization of the private security (Meško, Nalla, \& Sotlar, 2005). In addition to changes in the ownership structure that occurred in all post-socialist states, there were additional aggravating circumstances development of private security in the former
SFRY states: the independence of the former SFRY republics, war events, the rise of corruption and crime, the beginning of the privatization processes, a large number of unregistered weapons from the war environment, undeclared work, "laundering" of illegally acquired money, outbreaks of non-institutional debt collection and other activities of criminal groups (Meško, Tominc, \& Sotlar, 2013).

In the countries of the former Yugoslavia, the creation of private security first began in Slovenia, when, in the last decade of the $20^{\text {th }}$ century, the private security slowly became a "player" in the security market (Nalla, Meško, Sotlar, \& Johnson, 2006). According to researchers, the highest standards in the field of the private security have been reached by Slovenia and Croatia (Nikač, Korajlić, Ahić, \& Bećirović, 2013; Steden \& Sarre, 2010), while Serbia and Macedonia remained "the most problematic" (Steden \& Sarre, 2010). It was this statement that led the authors to investigate why these countries are "the most problematic". We have tried to determine in this paper whether this statement is correct, whether it has changed in the meantime, and whether the public in these countries views the private security as a "problem".

\section{LITERATURE REVIEW}

The number of papers related to research of the role of private security has not been as widespread in the $20^{\text {th }}$ century. By increasing the volume of work and the number of private security officers in the early $21^{\text {st }}$ century (Steden \& Sarre, $2007 \mathrm{a}, 2007 \mathrm{~b})$, there has also been an increase in the number of research in this area. Initially, research was mainly limited to the "western world", which is logi- cal, since this phenomenon has its roots in these areas, especially in the UK and the USA (Kesić, 2008). Research from this field started in more detail in Serbia and North Macedonia at the end of the first decade of the $21^{\text {st }}$ century, first in Serbia (Davidović, 2007, 2009; Kesić, 2008, 2009), while in North Macedonia such studies were encompassed by the broader research that enabled the overview of 
conditions in this field throughout the former SFRY (Steden \& Sarre, 2010).

Among the most extensive research on the private security, there has been the perception of citizens about the private security and its officers. This type of research covered two groups of respondents. The first group encompassed the respondents from the general population and of different ages (Moreira \& Cardoso, 2015; Petrevski \& Nikolovski, 2015; Steden \& Nalla, 2010). The second group included younger population, the students from different faculties (Kesić, 2008; Nalla, Gurinskaya, et al., 2017; Nalla \& Heraux, 2003; Nalla \& Hwang, 2004; Nalla \& Lim, 2003; Nalla et al., 2006a).

One of the first surveys in which the respondents were exclusively students or the younger population, was conducted in the US (Nalla \& Heraux, 2003), and the findings indicated that generally most students had a positive perception of private security officers. Similar results were found among the students in Singapore (Nalla \& Lim, 2003) and South Korea (Nalla \& Hwang, 2004). In contrast to the students in these countries, the students in Slovenia (Nalla et al., 2006a), Russia (Nalla, Gurinskaya, et al., 2017) and Serbia (Kesić, 2008) have stated that they generally do not have a positive view of private security officers. Unlike the first group of states, where the private security was at a higher level, in post-socialist countries such as Slovenia, it was still a country in transition with underdeveloped private security at the time of the survey. The private security service and its officers are not accepted by the younger population in post-socialist countries as in the countries with the developed market economies (Nalla et al., 2006a).

Some studies found differences in attitudes between genders, where the female population of respondents had more positive attitudes than the male population on certain segments of the private security. These segments were: nature (Nalla \& Heraux, 2003), goals (Nalla \& Heraux, 2003; Nalla \& Hwang, 2004) and the image of the private security business (Nalla \& Hwang, 2004), the professionalism of the private security officers (Nalla, Gurinskaya, et al., 2017; Nalla \& Heraux, 2003) and satisfaction with their work (Nalla, Gurinskaya, et al., 2017).

Numerous private security surveys conducted in different countries have bypassed the territory of Serbia and North Macedonia, the countries aspiring to become the members of the European Union. That is why the research aims to show what the situation in the aforementioned countries in this area is like and the perceptions of the younger population, security students, who have more comprehensive knowledge in this field, about private security and its officials.

\section{METHODS}

To assess respondents' perceptions of the private security and its employees, a survey was developed with items from previous surveys conducted in South Korea (Nalla \& Hwang, 2004), Slovenia (Nalla et al., 2006a), the Netherlands
(Steden \& Nalla, 2010) and Portugal (Moreira \& Cardoso, 2015). The survey was anonymous with close-ended, multiple-choice questions, and Likert scale questions (1 - strongly disagree; 5 - strongly agree). Participants were 
chosen randomly from a population of students from the University of Criminal Investigation and Police Studies in Belgrade, the Faculty of Security in Belgrade and the Faculty of Security in Skopje who voluntarily agreed to participate in the research. The survey data were collected from a total of 354 students, 296 from Serbia and 58 from North Macedonia. The survey was conducted during the summer semester of the $2018 / 2019$ school year.

\section{Analyses}

A multivariate regression analysis was used to test the variable 'gender' to validate our central hypothesis (Cvetković, 2019). Before moving on to the statistical test, we examined the general and specific underlying assumptions to ensure that they were appropriate. Preliminary testing checked the assumptions about normality, linearity, univariate and multivariate atypical points, homogeneity of variance-covariance matrices, and multicollinearity; more serious impairment of the assumptions was not observed (Cvetković, Öcal, \& Ivanov, 2019). The internal consistency of Likert scales for the 15 items is good with a Cronbach's alpha of 0.63 (Cvetković et al., 2019). In addition, ANOVA analysis was conducted for some appropriate variables.

\section{RESULTS}

\section{Demographic characteristics}

The research was carried out during 2019 and it consisted of 354 respondents: 296 from Serbia, and 58 from North Macedonia. The sample included $49.4 \%$ male $(\mathrm{N}=175)$ and $50.6 \%$ female $(\mathrm{N}=179)$ respondents. The average age of respondents was 22 years of age, and the most represented category was the one between 21 and 23 years of age. $17.95(\mathrm{~N}=63)$ respondents were with low income, and $82.05(\mathrm{~N}=288)$ respondents were with high income. The most of respondents lives in city area $64.4(\mathrm{~N}=228)$
(Table 1).To examine the central hypothesis of what gender is a predictable variable in all perceptions of private security, a multivariate regression analysis was used to identify the extent to which seven independent variables are related to three socio-economic variables: gender, age, and income (Cvetković, Roder, Öcal, Tarolli, \& Dragićević, 2018). Categories in Table 2, males, young, low income people have been coded as $1 ; 0$ have been assigned otherwise. 
Table 1. Demographic and socio-economic information of respondents $(N=354)$

\begin{tabular}{|c|c|c|c|c|c|c|}
\hline \multirow[b]{2}{*}{ Variable } & \multirow[b]{2}{*}{ Category } & \multicolumn{2}{|c|}{ Countries } & \multirow{2}{*}{$\begin{array}{c}\text { Total } \\
\mathrm{N}\end{array}$} & \multirow[b]{2}{*}{ Male } & \multirow[b]{2}{*}{ Female } \\
\hline & & $\begin{array}{l}\text { N. Macedonia } \\
\left(\mathrm{N}^{1}\right)\end{array}$ & Serbia $\left(\mathrm{N}^{2}\right)$ & & & \\
\hline \multirow{3}{*}{$\begin{array}{c}\text { Age } \\
\text { (years) }\end{array}$} & $18-20$ & $0(0)$ & $22(7.4 \%)$ & $\begin{array}{c}22 \\
(6.21 \%) \\
\end{array}$ & $10(5.7 \%)$ & $12(6.7 \%)$ \\
\hline & $21-23$ & $43(74.1 \%)$ & $\begin{array}{c}266 \\
(89.9 \%) \\
\end{array}$ & $\begin{array}{c}309 \\
(87.29 \%) \\
\end{array}$ & $\begin{array}{c}148 \\
(84.6 \%) \\
\end{array}$ & $\begin{array}{c}161 \\
(89.9 \%)\end{array}$ \\
\hline & +24 & $15(25.9 \%)$ & $8(2.7 \%)$ & $\begin{array}{c}23 \\
(6.50 \%) \\
\end{array}$ & $17(9.7 \%)$ & $6(3.4 \%)$ \\
\hline \multirow{2}{*}{ Income $^{\star}$} & $\begin{array}{l}\text { Low in- } \\
\text { come }\end{array}$ & $7(12.07 \%)$ & $56(19.1 \%)$ & $\begin{array}{c}63 \\
(17.95 \%) \\
\end{array}$ & $\begin{array}{c}28 \\
(16.18 \%) \\
\end{array}$ & $\begin{array}{c}145 \\
(83.82 \%) \\
\end{array}$ \\
\hline & $\begin{array}{l}\text { High in- } \\
\text { come }\end{array}$ & $51(87.93 \%)$ & $\begin{array}{c}237 \\
(80.89 \%) \\
\end{array}$ & $\begin{array}{c}288 \\
(82.05 \%)\end{array}$ & $\begin{array}{c}35 \\
(19.66 \%) \\
\end{array}$ & $\begin{array}{c}143 \\
(80.34 \%) \\
\end{array}$ \\
\hline \multirow{2}{*}{$\begin{array}{l}\text { Environ- } \\
\text { ment }\end{array}$} & City & 49 (84.5\%) & $\begin{array}{c}179 \\
(60.5 \%)\end{array}$ & $\begin{array}{c}228 \\
(64.4 \%) \\
\end{array}$ & $\begin{array}{c}111 \\
(63.4 \%)\end{array}$ & $\begin{array}{c}64 \\
(36.6 \%) \\
\end{array}$ \\
\hline & Village & $9(15.5 \%)$ & $\begin{array}{c}117 \\
(39.5 \%)\end{array}$ & $\begin{array}{c}126 \\
(35.6 \%)\end{array}$ & $\begin{array}{c}117 \\
(65.4 \%)\end{array}$ & $\begin{array}{c}62 \\
(34.6 \%) \\
\end{array}$ \\
\hline
\end{tabular}

$\mathrm{N}^{1}=58(19.53 \%), \mathrm{N}^{2}=239(80.47 \%)$

* National monthly average net salary

According to $\mathrm{Q}^{1}$ (Table 3 ) the results show that the most important predictor is gender $(\beta=-0.146)$. It explicates $14.6 \%$ variance. The remaining variables did not have significant effects. This model $\left(\mathrm{R}^{2}=0.031\right.$, Adj. $\mathrm{R}^{2}=.020$, $\mathrm{F}=2.75, \mathrm{t}=10.81, \mathrm{p}=0.000$ ) with all the mentioned independent variables explicates the $20 \%$ variance of perception that the private security officers are generally well educated. The results of the multivariate regressions of $\mathrm{Q}^{2}$ show that all variables did not have significant effects $\left(\mathrm{R}^{2}=0.020\right.$, Adj. $\mathrm{R}^{2}=.011, \mathrm{~F}=2.75$, $\mathrm{t}=2.30, \mathrm{p}=0.073)$ of perception that the private security officers are generally well trained. With regard to $\mathrm{Q}^{3}$ the results show that the most important predictor is gender $(\beta=-0.102)$. It explicates $10.2 \%$ variance. The remaining variables did not have significant effects. Model $\left(\mathrm{R}^{2}=0.024\right.$, Adj. $\mathrm{R}^{2}=.015, \mathrm{~F}=2.81, \mathrm{t}=9.76$, $\mathrm{p}=0.000)$ with all the mentioned independent variables explicates the 15\% variance of perception that the private security officers are generally well qualified. According to $\mathrm{Q}^{4}$ the results show that the most important predictor is gender $(\beta=-0.220)$. It explicates $22 \%$ variance followed by the age $(\beta=-0.106$, $10.6 \%)$. The income level did not have significant effects. Model $\left(\mathrm{R}^{2}=0.065\right.$, Adj. $\mathrm{R}^{2}=.057, \mathrm{~F}=8.07, \mathrm{t}=8.30, \mathrm{p}=0.000$ ) with all the mentioned independent variables explicates the $57 \%$ variance of perception that the private security officers first react (before the police) to the induced violence at sports events. With regard to $\mathrm{Q}^{5}$ the results show that the most important predictor is gender $(\beta=-$ $0.213)$. It explicates $21.3 \%$ variance. The remaining variables did not have significant effects. Model $\left(\mathrm{R}^{2}=0.045\right.$, Adj. $\left.\mathrm{R}^{2}=.036, \mathrm{~F}=5.38, \mathrm{t}=11.27, \mathrm{p}=0.000\right)$ with all the mentioned independent variables explicates the $36 \%$ variance of perception that the private security officers, while securing sports events, perform a good examination of persons when entering a sports facility. According to $\mathrm{Q}^{6}$ 
the results show that the most important predictor is gender $(\beta=-0.256)$. It explicates $25.6 \%$ variance. The remaining variables did not have significant effects. Model $\left(\mathrm{R}^{2}=0.068\right.$, Adj. $\mathrm{R}^{2}=.060$, $\mathrm{F}=5.38, \mathrm{t}=11.27, \mathrm{p}=0.000)$ with all the mentioned independent variables explicates the $60 \%$ variance of perception that the private security officers provide good and successful security services at sports events. In addition, according to $\mathrm{Q}^{7}$ the results show that the most important predictor is gender $(\beta=-0.239)$. It explicates $23.9 \%$ variance. The remaining variables did not have significant effects. Model $\left(\mathrm{R}^{2}=0.063\right.$, Adj. $\mathrm{R}^{2}=.055$, $\mathrm{F}=7.70, \mathrm{t}=12.02, \mathrm{p}=0.000)$ with all the mentioned independent variables explicates the 55\% variance of the perception that the private security officers are good at coping with emergencies. The results of the multivariate regressions of $\mathrm{Q}^{8}$ show that all variables did not have sig- nificant effects $\left(\mathrm{R}^{2}=0.022\right.$, Adj. $\mathrm{R}^{2}=.014$, $\mathrm{F}=2.75, \mathrm{t}=2.60, \mathrm{p}=0.063)$ of perception that private security officers are generally helpful. Also, the results of the multivariate regressions of $\mathrm{Q}^{9}$ show that all variables did not have significant effects $\left(\mathrm{R}^{2}=0.016\right.$, Adj. $\mathrm{R}^{2}=.007, \mathrm{~F}=1.85, \mathrm{t}=2.60$, $\mathrm{p}=0.138$ ) of perception that private security officers are generally helpful. According to $\mathrm{Q}^{10}$ the results show that the most important predictor is gender $(\beta=-$ $0.141)$. It explicates $14.1 \%$ variance. The remaining variables did not have significant effects. Model $\left(\mathrm{R}^{2}=0.020\right.$, Adj. $\left.\mathrm{R}^{2}=.012, \mathrm{~F}=2.35, \mathrm{t}=10.02, \mathrm{p}=0.000\right)$ with all the mentioned independent variables explicates the $12 \%$ variance of perception that private security officers do their job professionally (Table 3 ). Guided by the results obtained, we can validate our hypothesis that gender is an important variable in the context of examining perception regarding private security.

Table 2. Multivariate regression analysis results

in predicting perception of private security officers ${ }^{2}$

\begin{tabular}{cccccccccc}
\hline \multirow{2}{*}{$\begin{array}{c}\text { Predictor } \\
\text { variable }\end{array}$} & \multicolumn{3}{c}{ Gender } & \multicolumn{3}{c}{ Age } & \multicolumn{3}{c}{ Income level } \\
\cline { 2 - 10 } & $\mathrm{B}$ & $\mathrm{SE}$ & $\beta$ & $\mathrm{B}$ & $\mathrm{SE}$ & $\beta$ & $\mathrm{B}$ & $\mathrm{SE}$ & $\beta$ \\
\hline $\mathrm{Q}^{1}$ & -.277 & .101 & $-.146^{*}$ & .258 & .206 & .067 & -.147 & .135 & -.059 \\
$\mathrm{Q}^{2}$ & -.223 & .119 & -.100 & .322 & .242 & .072 & .119 & .156 & .041 \\
$\mathrm{Q}^{3}$ & -.238 & .125 & $-.102^{\star}$ & .362 & .253 & .077 & .186 & .164 & .061 \\
$\mathrm{Q}^{4}$ & -.531 & .126 & $-.220^{* *}$ & .515 & .257 & $.106^{*}$ & -.031 & .166 & -.010 \\
$\mathrm{Q}^{5}$ & -.532 & .132 & $-.213^{* *}$ & -.194 & .269 & -.038 & -.041 & .173 & -.013 \\
$\mathrm{Q}^{6}$ & -5.44 & .111 & $-.256^{*}$ & .098 & .226 & .023 & .042 & .145 & .015 \\
$\mathrm{Q}^{7}$ & -.487 & .107 & -.239 & .098 & .218 & .204 & .135 & .140 & .050 \\
$\mathrm{Q}^{8}$ & -.239 & .112 & -.115 & .215 & .226 & .056 & .161 & .147 & .059 \\
$\mathrm{Q}^{9}$ & -.246 & .110 & -.12 & -.215 & .223 & -.052 & -.033 & .145 & -012 \\
$\mathrm{Q}^{10}$ & -.295 & .113 & -.141 & .028 & .228 & .007 & -.009 & .147 & -.003 \\
\hline${ }^{*} \mathrm{p}=.05 .^{* *} \mathrm{p} \leq .01$. & & & & & & & &
\end{tabular}

$2 \mathrm{Q}^{1}$ - Private security officers are well educated; $\mathrm{Q}^{2}$ - Private security officers are well trained; $\mathrm{Q}^{3}$ Private security officers are well qualified; $\mathrm{Q}^{4}$ - Private security officers are the first to react (before the police) to the provoked violence at sports events; $Q^{5}$ - Private security officers, while securing sports events, search people well at entering the sports facility; $\mathrm{Q}^{6}$ - Private security officers secure sport events well and successfully; $\mathrm{Q}^{7}$ - Private security officers are good at dealing with emergency situations; $\mathrm{Q}^{8}$ - Private security officers are generally helpful; $\mathrm{Q}^{9}$ - Private security officers kindly receive calls for help; $\mathrm{Q}^{10}$ - Private security officers do their job professionally. 


\section{Perception of private security officers}

One-factor multivariate analysis of variance explored gender differences in the perception of the private security officers. On this occasion, 10 dependent variables $\left(\mathrm{Q}^{1}-\mathrm{Q}^{10}\right)$ were used and the independent variable was gender. A statistically significant difference was found between males and females regarding the combination of dependent variables $\mathrm{F}$
$(10,327)=3.57, \mathrm{p}=0.000$; Wilks' Lamb$\mathrm{da}=.902$. When the results of dependable variables were examined individually, it was determined that the following differences had reached statistical significance (together with Bonferroni adjusted alpha level of 0.005$): \mathrm{Q}^{1}-\mathrm{F}(1,327)=$ 7.27, $\mathrm{p}=0.005 ; \eta \mathrm{p}^{2}=0.02$.

Table 3. Perception of private security officers ${ }^{3}$

\begin{tabular}{|c|c|c|c|c|c|c|c|c|c|c|c|c|c|}
\hline & \multicolumn{2}{|c|}{ Serbia } & \multicolumn{2}{|c|}{$\begin{array}{l}\text { N. Mace- } \\
\text { donia }\end{array}$} & \multicolumn{2}{|c|}{ Total } & \multicolumn{2}{|c|}{ Male } & \multicolumn{2}{|c|}{ Female } & \multirow[t]{2}{*}{$\mathbf{F}$} & \multirow[t]{2}{*}{ Sig. } & \multirow[t]{2}{*}{$\eta p^{2}$} \\
\hline & $X$ & $\mathrm{SD}$ & $\mathrm{X}$ & $\mathrm{SD}$ & $X$ & SD & $X$ & $\mathrm{SD}$ & $X$ & $\mathrm{SD}$ & & & \\
\hline $\mathrm{Q}^{1}$ & 2.50 & .95 & 2.45 & .96 & 2.50 & .95 & 2.35 & 1.00 & 2.63 & .88 & 7.23 & $.005^{\star}$ & .02 \\
\hline $\mathrm{Q}^{2}$ & 2.83 & 1.12 & 2.94 & 1.05 & 2.85 & 1.11 & 2.72 & 1.14 & 2.96 & 1.05 & 4.01 & .046 & .01 \\
\hline $\mathrm{Q}^{3}$ & 2.74 & 1.16 & 2.92 & 1.19 & 2.77 & 1.16 & 2.65 & 1.19 & 2.88 & 1.10 & 3.38 & .067 & .01 \\
\hline $\mathrm{Q}^{4}$ & 2.38 & 1.19 & 2.42 & 1.26 & 2.38 & 1.20 & 2.10 & 1.14 & 2.69 & 1.18 & 18.20 & $.000^{* *}$ & .05 \\
\hline $\mathrm{Q}^{5}$ & 2.58 & 1.26 & 2.89 & 1.12 & 2.63 & 1.24 & 2.41 & 1.28 & 2.87 & 1.17 & 11.73 & $.001^{\star *}$ & .03 \\
\hline $\mathrm{Q}^{6}$ & 2.68 & 1.05 & 2.83 & 1.12 & 2.70 & 1.06 & 2.46 & 1.06 & 2.97 & .97 & 21.47 & $.000^{\star *}$ & .06 \\
\hline $\mathrm{Q}^{7}$ & 2.48 & 1.01 & 2.80 & 1.04 & 2.53 & 1.02 & 2.31 & 1.02 & 2.76 & 1.02 & 17.87 & $.000^{\star *}$ & .50 \\
\hline $\mathrm{Q}^{8}$ & 3.23 & 1.02 & 3.01 & 1.12 & 3.20 & 1.04 & 3.07 & 1.13 & 3.32 & .92 & 4.94 & .027 & .01 \\
\hline $\mathrm{Q}^{9}$ & 2.87 & 1.01 & 3.01 & 1.06 & 2.89 & 1.02 & 2.79 & 1.05 & 2.99 & .98 & 3.18 & .075 & .00 \\
\hline $\mathrm{Q}^{10}$ & 2.39 & 1.02 & 2.67 & 1.14 & 2.44 & 1.04 & 2.29 & 1.11 & 2.56 & .96 & 5.61 & .018 & .01 \\
\hline
\end{tabular}

An overview of the average values of the results revealed that in female population $(\mathrm{M}=2.63, \mathrm{SD}=.072)$ there were slightly higher levels of perception about the levels of education of security officers noticed than at male population $(\mathrm{M}=2.35, \mathrm{SD}=.073) ; \mathrm{Q}^{4}-\mathrm{F}(1,327)=$ $18.20, \mathrm{p}=0.000 ; \eta \mathrm{p}^{2}=0.05$. An overview of the average values of the results revealed that there were slightly higher levels of perception that private security officers react first to the provoked violence at sports events noticed in females $(\mathrm{M}=2.69, \mathrm{SD}=1.18)$ than in males $(\mathrm{M}=$ $2.10, \mathrm{SD}=1.14) ; \mathrm{Q}^{5}-\mathrm{F}(1,327)=7.27$, $p=0.005 ; \eta p^{2}=0.021$. An overview of the average values of the results revealed that there were slightly higher levels of perception that private security officers search a person well at entering a sports

$3 \mathrm{Q}^{1}$ - Private security officers are well educated; $\mathrm{Q}^{2}$ - Private security officers are well trained; $\mathrm{Q}^{3}$ Private security officers are well qualified; $\mathrm{Q}^{4}$ - Private security officers are the first to react (before the police) to the provoked violence at sports events; $Q^{5}$ - Private security officers, while securing sports events, search people well at entering the sports facility; $\mathrm{Q}^{6}$ - Private security officers secure sport events well and successfully; $\mathrm{Q}^{7}$ - Private security officers are good at dealing with emergency situations; $\mathrm{Q}^{8}$ - Private security officers are generally helpful; $\mathrm{Q}^{9}$ - Private security officers kindly receive calls for help; $\mathrm{Q}^{10}$ - Private security officers do their job professionally. 
facility noticed in females $(\mathrm{M}=2.87, \mathrm{SD}$ $=1.17)$ than in males $(\mathrm{M}=2.41, \mathrm{SD}=$ 1.28); $\mathrm{Q}^{6}-\mathrm{F}(1,327)=21.47, \mathrm{p}=0.000$; $\eta \mathrm{p}^{2}=0.06$. An overview of the average values of the results revealed that there were slightly higher levels of perception that private security officers secure sports events well and successfully noticed in female population $(\mathrm{M}=2.97, \mathrm{SD}=.097)$ than in male population $(\mathrm{M}=2.46, \mathrm{SD}$ $=1.06) ; \mathrm{Q}^{7}-\mathrm{F}(1,327)=7.27, \mathrm{p}=0.005$; $\eta \mathrm{p}^{2}=0.021$. An overview of the average results showed that a slightly higher level of perception of the level of education of private security officers was observed in females $(\mathrm{M}=2.63, \mathrm{SD}=.072)$ than in males $(\mathrm{M}=2.35, \mathrm{SD}=.073)$.

\section{Perception of integrity of private security officers}

To examine the perception of integrity of private security officers, one-factor multivariate analysis of variance and 6 dependent variables were used $\left(\mathrm{Q}^{11}\right.$ $-\mathrm{Q}^{16}$ ) with gender as an independent variable. A statistically significant difference was found between males and females regarding the combination of dependent variables $\mathrm{F}(6,327)=2.72, \mathrm{p}=$ 0.013; Wilks' Lambda $=.954$. When the results of the dependent variables were considered separately, the following differences were found to reach statistical significance (together with Bonferroni adjusted alpha level of 0.008): $\mathrm{Q}^{11}-\mathrm{F}$ $(1,327)=12.80, p=0.000 ; \eta p^{2}=0.03$. An overview of the average values of the results revealed that there were slightly higher levels of perception that the existing monitoring of private security officers' work is more effective observed in females $(\mathrm{M}=2.81, \mathrm{SD}=.076)$ than in males $(M=2.46, S D=1.00)$. In other dependent variables, no statistically significant difference was found between males and females (Table 4).

Table 4. Perception of integrity of private security officers ${ }^{4}$

\begin{tabular}{|c|c|c|c|c|c|c|c|c|c|c|c|c|c|}
\hline & \multicolumn{2}{|c|}{ Serbia } & \multicolumn{2}{|c|}{$\begin{array}{l}\text { N. Mace- } \\
\text { donia }\end{array}$} & \multicolumn{2}{|c|}{ Total } & \multicolumn{2}{|c|}{ Male } & \multicolumn{2}{|c|}{ Female } & \multirow[t]{2}{*}{$F$} & \multirow[t]{2}{*}{ Sig. } & \multirow[t]{2}{*}{$\eta p^{2}$} \\
\hline & $X$ & $\mathrm{SD}$ & $X$ & $\mathrm{SD}$ & $X$ & SD & $X$ & $\mathrm{SD}$ & $X$ & $\mathrm{SD}$ & & & \\
\hline $\mathrm{Q}^{11}$ & 2.63 & .87 & 2.67 & 1.06 & 2.64 & .91 & 2.46 & 1.00 & 2.81 & .76 & 12.80 & $.000^{\star *}$ & .03 \\
\hline $\mathrm{Q}^{12}$ & 2.66 & .91 & 2.93 & 1.07 & 2.70 & .94 & 2.60 & 1.02 & 2.82 & .84 & 3.95 & .048 & .01 \\
\hline $\mathrm{Q}^{13}$ & 2.87 & .90 & 3.08 & 1.27 & 2.91 & .97 & 2.79 & 1.03 & 3.02 & .91 & 4.55 & .034 & .01 \\
\hline $\mathrm{Q}^{14}$ & 3.22 & 1.04 & 3.12 & 1.15 & 3.20 & 1.06 & 3.24 & 1.19 & 3.16 & .90 & .51 & .471 & .00 \\
\hline $\mathrm{Q}^{15}$ & 2.90 & 1.15 & 2.74 & 1.26 & 2.88 & 1.17 & 2.80 & 1.29 & 2.95 & 1.02 & 1.38 & .242 & .00 \\
\hline $\mathrm{Q}^{16}$ & 2.77 & .92 & 2.91 & 1.08 & 2.80 & .95 & 2.69 & 1.03 & 2.91 & .85 & 4.72 & .031 & .01 \\
\hline
\end{tabular}

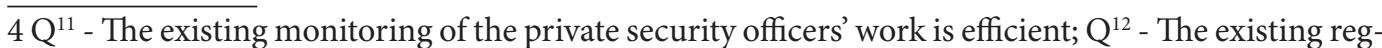
ulations are adequate for the control of work of private security officers; $\mathrm{Q}^{13}$ - Private security officers have numerous discretionary powers; $\mathrm{Q}^{14}$ - Private security officers abuse their powers; $\mathrm{Q}^{15}$ - Private security officers are responsible when they exceed their authority; $\mathrm{Q}^{16}$ - Private security officers are generally honest. 


\section{Perception of the job of private security officers}

Results of one-factor multivariate analysis of variance (8 dependent variables $\left(\mathrm{Q}^{17}-\mathrm{Q}^{24}\right)$ with gender as an independent variable) show that a statistically significant difference was found between males and females regarding the combination of dependent variables $\mathrm{F}(8,327)=4.24, \mathrm{p}=0.000$; Wilks' Lambda $=.904$. When the results of the dependent variables were considered separately, it was determined that the following differences reached statistical significance (together with Bonferroni adjusted alpha level of 0.006$): \mathrm{Q}^{21}-\mathrm{F}(1$, $327)=12.71, \mathrm{p}=0.000 ; \eta \mathrm{p}^{2}=0.037$. An overview of the average values of the results revealed that slightly higher levels of perception that the private security officer's job is more paid were observed in female population $(\mathrm{M}=2.78, \mathrm{SD}=$
.99) than in male population $(\mathrm{M}=2.37$, $\mathrm{SD}=1.08) ; \mathrm{Q}^{22}-\mathrm{F}(1,327)=10.12, \mathrm{p}$ $=0.002 ; \eta p^{2}=0.03$. An overview of the average values of the results determined that slightly higher levels of perception that the private security officer's job is more paid were observed in females $(M$ $=1.72, \mathrm{SD}=.76)$ than in males $(\mathrm{M}=$ $1.72, \mathrm{SD}=.90) ; \mathrm{Q}^{23}-\mathrm{F}(1,327)=7.88$, $p=0.005 ; \eta p^{2}=0.023$. An overview of the average values of the results determined that in females $(\mathrm{M}=2.82, \mathrm{SD}=$ 1.06) there are slightly smaller levels of perception that the primary role of a private security officer is to arrest suspects observed than in males $(M=3.15$, $\mathrm{SD}=1.17)$. As for other dependent variables, no statistically significant difference was found between males and females (Table 5).

Table 5. Perception of the job of private security officers ${ }^{5}$

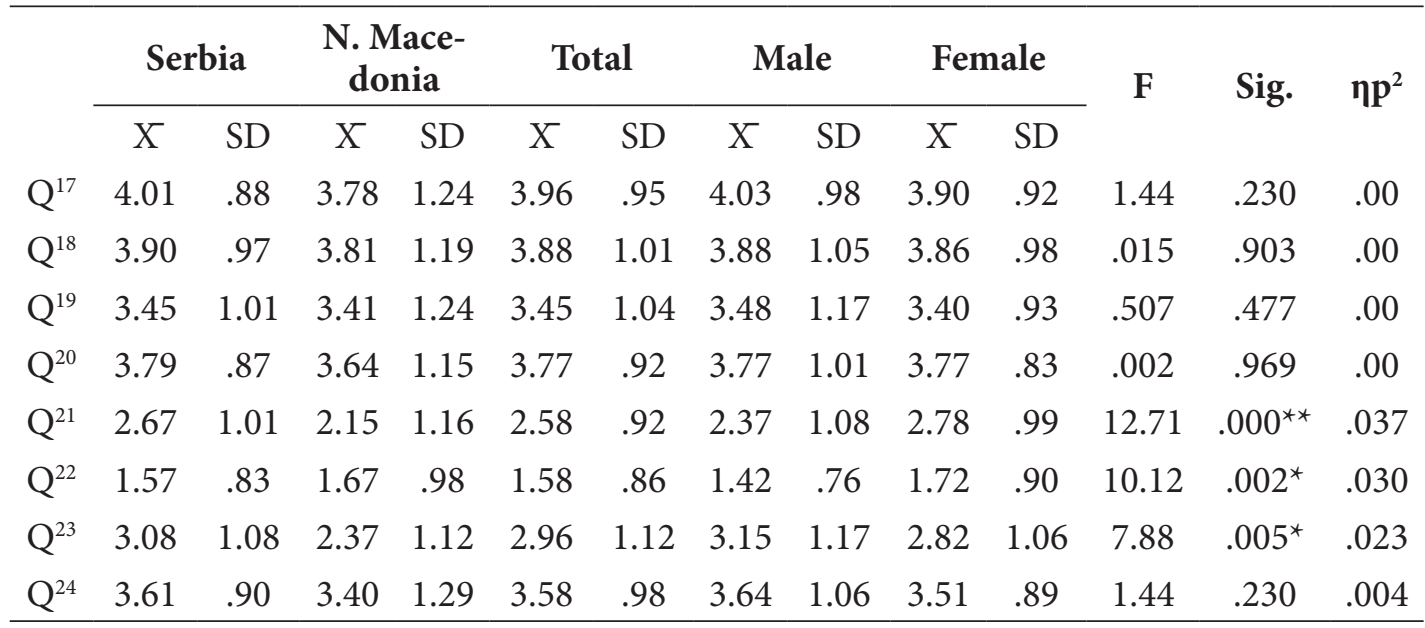
${ }^{\star} \mathrm{p}=.05 .{ }^{* *} \mathrm{p} \leq .01$.

\section{Satisfaction of citizens with private security officers}

The results of one-factor multivariate bles $\left(\mathrm{Q}^{25}-\mathrm{Q}^{28}\right)$ show that there is no staanalysis of variance ( 4 dependent varia- tistically significant difference between $5 \mathrm{Q}^{17}$ - A security officer's job is dangerous; $\mathrm{Q}^{18}$ - Private security exceed are exposed to high risk of being injured during work; $\mathrm{Q}^{19}$ - Private security job is complex; $\mathrm{Q}^{20}$ - Private security job is stressful; $\mathrm{Q}^{21}$ - Private security job is well paid; $\mathrm{Q}^{22}$ - The primary role of a private security officer is to arrest the suspects; $\mathrm{Q}^{23}$ - Private security job helps reduce losses for the company; $\mathrm{Q}^{24}$ - Private security job helps in protection of clients. 
males and females regarding the combination of dependent variables $\mathrm{F}(4,327)$ $=1.95, \mathrm{p}=0.101 ;$ Wilks' Lambda $=.978$. When the results of the dependent variables were considered separately, it was determined that the following differences reached statistical significance (together with Bonferroni adjusted alpha level of 0.001) (Table 6).

Table 6. Satisfaction of citizens with private security officers ${ }^{6}$

\begin{tabular}{|c|c|c|c|c|c|c|c|c|c|c|c|c|c|}
\hline & \multicolumn{2}{|c|}{ Serbia } & \multicolumn{2}{|c|}{$\begin{array}{l}\text { N. Mace- } \\
\text { donia }\end{array}$} & \multicolumn{2}{|c|}{ Total } & \multicolumn{2}{|c|}{ Male } & \multicolumn{2}{|c|}{ Female } & \multirow[t]{2}{*}{$\mathbf{F}$} & \multirow{2}{*}{ Sig. } & \multirow{2}{*}{$\eta p^{2}$} \\
\hline & $\mathrm{X}$ & $\mathrm{SD}$ & $\overline{\mathrm{X}}$ & $\mathrm{SD}$ & $\overline{\mathrm{X}}$ & $\mathrm{SD}$ & $\overline{\mathrm{X}}$ & $\mathrm{SD}$ & $\overline{\mathrm{X}}$ & SD & & & \\
\hline$Q^{25}$ & 2.75 & 1.12 & 2.62 & 1.10 & 2.73 & 1.12 & 2.61 & 1.17 & 2.85 & 1.05 & 3.99 & .047 & .011 \\
\hline $\mathrm{Q}^{26}$ & 2.79 & .95 & 3.01 & 1.09 & 2.83 & .98 & 2.76 & 1.03 & 2.89 & .92 & 1.63 & 202 & .005 \\
\hline $\mathrm{Q}^{27}$ & 2.71 & .94 & 2.89 & .98 & 2.74 & .95 & 2.64 & .98 & 2.84 & .90 & 3.61 & .058 & .010 \\
\hline $\mathrm{Q}^{28}$ & 2.69 & .99 & 3.02 & .94 & 2.75 & .98 & 2.62 & .98 & 2.88 & .97 & 6.16 & .023 & .017 \\
\hline
\end{tabular}

\section{Private security and the police}

The results of one-factor multivariate tween males and females regarding the analysis of variance (7 dependent varia- combination of dependent variables $\mathrm{F}$ bles (Q29 - Q35) show that there is no $(7,327)=4.24, \mathrm{p}=0.000$; Wilks' Lambstatistically significant difference be- $\mathrm{da}=.904$.)

Table 7. Private security and the police

\begin{tabular}{|c|c|c|c|c|c|c|c|c|c|c|c|c|c|}
\hline & \multicolumn{2}{|c|}{ Serbia } & \multicolumn{2}{|c|}{$\begin{array}{c}\text { N. Mace- } \\
\text { donia }\end{array}$} & \multicolumn{2}{|c|}{ Total } & \multicolumn{2}{|c|}{ Male } & \multicolumn{2}{|c|}{ Female } & \multirow[t]{2}{*}{$\mathbf{F}$} & \multirow{2}{*}{ Sig. } & \multirow{2}{*}{$\eta p^{2}$} \\
\hline & $X$ & SD & $\mathrm{X}$ & SD & $\mathrm{X}$ & SD & $X$ & SD & $\mathrm{X}$ & SD & & & \\
\hline $\mathrm{Q}^{29}$ & 2.27 & 1.00 & 2.31 & 1.04 & 2.28 & 1.01 & 2.17 & .076 & 2.39 & .076 & 4.37 & .037 & .01 \\
\hline $\mathrm{Q}^{30}$ & 1.75 & 1.01 & 1.70 & 1.02 & 1.74 & 1.01 & 1.61 & .076 & 1.88 & .076 & 6.30 & .013 & .018 \\
\hline $\mathrm{Q}^{31}$ & 2.97 & 1 & 3.24 & 1.34 & 3.02 & 01 & 3.16 & 1099. & 2.88 & .099 & 4.11 & .043 & .012 \\
\hline $\mathrm{Q}^{32}$ & 2.97 & 1.22 & 3.05 & 1.06 & 2.98 & .19 & 2.98 & .091 & 2.98 & .090 & .002 & .966 & .000 \\
\hline $\mathrm{Q}^{33}$ & 2.89 & .21 & 2.63 & 1.13 & 2.84 & 1.20 & 2.74 & .091 & 2.95 & .090 & 2.73 & .099 & .008 \\
\hline $\mathrm{Q}^{34}$ & 2.53 & 1.05 & 2.63 & 1.10 & 2.55 & 1.06 & 2.48 & .081 & 2.62 & .080 & 1.55 & .214 & .004 \\
\hline $\mathrm{Q}^{35}$ & 2.33 & 1.03 & 2.32 & 1.03 & 2.33 & 1.03 & 2.25 & .078 & 2.40 & .078 & 1.85 & .174 & .005 \\
\hline
\end{tabular}

$6 \mathrm{Q}^{25}$ - I feel safe when I see a private security officer nearby; $\mathrm{Q}^{26}$ - Generally, I am satisfied with the private security officer's behaviour; $\mathrm{Q}^{27}$ - Citizens are generally satisfied with the behaviour of private security officers; $\mathrm{Q}^{28}$ - Citizens generally trust private security officers when protecting their lives and property. $7 \mathrm{Q}^{29}$ - Private security officers and police officers often work together to solve crimes; $\mathrm{Q}^{30}$ - Private security officers are difficult to distinguish from police officers; $\mathrm{Q}^{31}$ - Private security officers and police officers should work together; $\mathrm{Q}^{32}$ - Private security officers and police officers protect the social community from crime together; $\mathrm{Q}^{33}$ - In the future, many police functions will be transferred to the responsibility of private security agencies; $\mathrm{Q}^{34}$ - The security job is generally structured similarly a police job; $\mathrm{Q}^{35}$ - Private security agencies are organized as police organizations. 
When the results of the dependent variables were considered separately, it was determined that the following dif- ferences did not reach statistical significance (together with Bonferroni adjusted alpha level of 0.007) (Table 7).

\section{DISCUSSION}

The results of the research indicate that the perception of students of Serbia and North Macedonia of private security officers and their business do not differ drastically. In both countries the attitudes are heterogeneous, but a relatively small number of respondents expressed a high level of perception of private security, i.e. the opinion of the majority of respondents is at a medium or low level of perception. Compared to the previous period in Serbia, a slight increase in confidence in private security can be noted, since the survey conducted by Kesić (2008). Although only basic analyses were conducted, more than half of the respondents did not have any praise for a certain segment of private security work, and only 29 respondents (out of 266) gave a positive assessment of a particular segment of private security work. In North Macedonia, the obtained results are in line with previous studies (Vankovska, 2016) because a relatively small number of respondents expressed a high level of perception, that is, the opinion of most respondents is at a medium or low level of perception of the private security. Similar results were obtained in Slovenia, in a survey conducted in 2004 (Nalla et al., 2006a) and in a study conducted in Russia (Nalla et al., 2017). All of these countries are former socialist states where private security and market economy were still under development at the time of the survey. The mentioned research in Slovenia was conducted in 2004, when it was admitted to the EU, i.e. when it fulfilled the conditions for full membership, so that it can be concluded that the private security industry was under development at that time.

In contrast to former socialist states, in the studies conducted in countries where market economics and private security have a longer tradition, such as America (Nalla \& Heraux, 2003), Singapore (Nalla \& Lim, 2003), South Korea (Nalla \& Hwang, 2004), the results obtained were inconsistent with the results of this research. They indicate that generally most students have a positive perception of private security and the nature of the private security business. All of the above shows that it takes time to establish confidence in the private security industry, and to enhance the level of professionalism. Most respondents rated the private security business as dangerous, complex, and stressful, and that private security officers are at high risk of injury, which is consistent with other research findings (Nalla \& Heraux, 2003; Nalla \& Hwang, 2004; Steden \& Nalla, 2010). The research has shown that gender, as one of its demographic characteristics, plays a role in shaping young people's views on private security. Compared to the male population, females have a more positive view of private security, the integrity of private security, and the nature of private security work. With respect to the female population, similar results were obtained in the studies conducted in America (Nalla \& Heraux, 2003) in relation to the nature and goals of the private security business in Russia (Nalla, Gurinskaya, et al., 2017) on the perception of private 
security officers, in South Korea (Nalla \& Hwang, 2004) where the female population had a more positive view of the goals of the private security business. It should be borne in mind that the number of male respondents in the study was higher than the female population.

\section{CONCLUSION}

The results of an empirical study indicate that the public, especially the younger population, in transition societies such as Serbia and North Macedonia, do not have a high degree of positive perception of private security. Compared to earlier research, it can be perceived that the attitudes of young people in Serbia towards private security officers are more favourable than they were before, while in North Macedonia they remained at a similar level. The public should get used to the transition from a society where the police were the only ones in charge of citizens' security, while in societies with the regulated market economy, a great part of that role was taken over by the private security industry.

The research findings indicate that the female population has a better perception of the private security. These findings offer policy makers and private security companies the opportunity to deploy new strategies to upgrade public attitudes towards private security, especially aimed at the male population. Also, the results of this study indicate the importance of the role and training of private security officers in shaping citizens' confidence in them.

The authors are aware that the findings have their limitations because the research was conducted only within a narrow population of young students, and the results obtained cannot be generalized because there are no views of the wider population in the paper. It would be particularly interesting to see in the future research the views of the citizens of Serbia and North Macedonia born in the age of socialism when there were no private security companies, and whether their views differ from those of the young population.

\section{REFERENCES}

1. Cvetković, V.M. (2019). Risk Perception of Building Fires in Belgrade. International Journal of Disaster Risk Management, 1(1), 81-91. doi:10.18485/ijdrm.2019.1.1.5

2. Davidović, D. (2007). Klasifikacije and tumačenja privatnog polisinga / Classification and explanation of private policing. Zbornik Instituta za kriminološka and sociološka istraživanja, 26(1-2), 389-397.

3. Davidović, D. (2009). Public-private security sector partnership in Serbia: Problems and future development. Varstvoslovje, 11(2), 345-351.

4. Hansen, L.C., Loftus, B., \& Loader, I. (2016). Doing 'dirty work': Stigma and esteem in the private security industry. European Journal of Criminology, 13(3), 297-314. doi:10.1177/1477370815615624 
5. Kesić, Z. (2008). Ispitivanje stavova studenata Kriminalističko-policijske akademije o privatnom policijskom delovanju / Survey of attitudes of students of The Academy of Criminalistic and Police Studies towards private policing. NBP Journal of Criminalistics and Law, 13(2); 171-185.

6. Kesić, Z. (2009). Specifični pojavni oblici private security u svetu / Specific forms of private security worldwide. Bezbednost, 51(1-2); 193-207.

7. Meško, G., Nalla, M.K., \& Sotlar, A. (2004). Youth Perception of Private Security in Slovenia: Preliminary Findings. In G. Meško, M. Pagon, \& B. Dobovšek (Eds.), Policing in Central and Eastern Europe: Dilemmas of Contemporary Criminal Justice (pp. 745-752). Maribor: University of Maribor, Faculty of Criminal Justice.

8. Meško, G., Nalla, M.K., \& Sotlar, A. (2005). Policisti in zasebni varnostniki - veliki in mali bratje. Journal of Criminal Investigation and Criminology, 56(2), 147-162.

9. Meško, G., Tominc, B., \& Sotlar, A. (2013). Urban security management in the capitals of the former Yugoslav republics. European Journal of Criminology, 10(3), 284-296. doi:10.1177/1477370812473537

10. Moreira, S., Cardoso, C., \& Nalla, M.K. (2015). Citizen confidence in private security guards in Portugal. European Journal of Criminology, 12(2), 208-225. doi:10.1177/1477370815571946

11. Nalla, M.K., Gurinskaya, A., \& Rafailova, D. (2017). Youth Perceptions of Private Security Guard Industry in Russia. Journal of Applied Security Research, 12(4), 543-556. doi:10.1080/19361610.2017.1354277

12. Nalla, M.K., \& Heraux, C.G. (2003). Assessing goals and functions of private police. Journal of Criminal Justice, 31(3), 237-247. doi:10.1016/s00472352(03)00005-9

13. Nalla, M.K., \& Hwang, (. (2004). Assessing professionalism, goals, images, and nature of private security in South Korea. Asian Policing, 2(1), 104-121.

14. Nalla, M.K., \& Lim, S.S. (2003). Students' perceptions of private police in Singapore. Asian Policing, 1(1), 27-47.

15. Nalla, M.K., Maxwell, S.R., \& Mamayek, C.M. (2017). Legitimacy of Private Police in Developed, Emerging, and Transitional Economies. European Journal of Crime, Criminal Law and Criminal Justice, 25(1), 76-100. doi:10.1163/15718174-25012107

16. Nalla, M.K., Meško, G., Sotlar, A., \& Johnson, J.D. (2006). Professionalism, Goals and the Nature of Private Police in Slovenia. Varstvoslovje, 8(3-4), 309-322.

17. Nikač, Ž., Korajlić, N., Ahić, J., \& Bećirović, M. (2013). Pravna regultiva private security na prostorima nekadašnje SFRY sa osvrtom na poslednje promene $u$ Srbiji / Regulatory private security in the former Yugoslavia, with emphasis on the recent changes in Serbia. Kriminalističke teme, (3-4), 7-52.

18. Paek, S.Y., Nalla, M.K., \& Lee, J. (2018). Perception of police legitimacy among private security officers. Security Journal, 32(3), 287-305. doi:10.1057/s41284018-00163-5 
19. Petrevski, B., \& Nikolovski, M. (2015). The role of the subjects of the private security subsistem in the Republic of Macedonia in providing security in urban areas. Zbornik radova: Naučna konferencija Dani kriminalističkih nauka (pp. 7-15). Sarajevo: Fakultet za kriminalistiku, kriminologiju and sigurnosne studije.

20. Steden, R.V., \& Sarre, R. (2007). The Growth of Private Security: Trends in the European Union. Security Journal, 20(4), 222-235. doi:10.1057/palgrave.sj.8350052

21. Steden, R.V., \& Sarre, R. (2007). The Growth of Privatized Policing: Some Crossnational Data and Comparisons. International Journal of Comparative and Applied Criminal Justice, 31(1), 51-71. doi:10.1080/01924036.2007.9678760

22. Steden, R.V., \& Nalla, M.K. (2010). Citizen satisfaction with private security guards in the Netherlands: Perceptions of an ambiguous occupation. European Journal of Criminology, 7(3), 214-234. doi:10.1177/1477370809359264

23. Steden, R.V., \& Sarre, R. (2010). Private policing in the former Yugoslavia: A menace to society? Varstvoslovje, 12(4), 424-439.

24. Vankovska, B. (2016). Privatniot bezbednosen sektor vo Republika Makedonija: Megu potrebite and javnata (ne)doverba / Private security sector in the Republic of Macedonia: Between needs and public (un)trust. Skopje: Komora na Republika Makedonija za privatno obezbeduvanje. 